\title{
An Empirical Analysis of Effectiveness of Monetary and Fiscal Policy Instruments in Stabilizing Economy: Evidence from Nigeria
}

\author{
Adewale Emmanuel Adegoriola \\ Department of Economics, University of Abuja, Abuja, Nigeria
}

Email address:

adegoriolae@yahoo.com

\section{To cite this article:}

Adewale Emmanuel Adegoriola. An Empirical Analysis of Effectiveness of Monetary and Fiscal Policy Instruments in Stabilizing Economy: Evidence from Nigeria. Social Sciences. Vol. 7, No. 3, 2018, pp. 133-140. doi: 10.11648/j.ss.20180703.14

Received: October 30, 2017; Accepted: May 8, 2018; Published: May 18, 2018

\begin{abstract}
This paper empirical study the effectiveness of monetary and fiscal policy instruments in stabilizing Nigerian economy from 1981 - 2015. The data were sourced from Central Bank of Nigeria, National Bureau of Statistics and World Development Index (WDI). The data was tested for stationarity using Augmented Dickey Fuller (ADF test while the cointegration was conducted using Johansen's methodology. Error Correction Model (ECM) was employed for the empirical analysis. The results show that, there is long run equilibrium relationship between monetary and fiscal policy instruments and economic growth in Nigeria. ECM has the expected negative sign and is between the accepted region of less than unity. This was confirmed by the positive relationship between money supply, government expenditure and revenue while interest rate and budget deficit have negative relationship with economic growth. Therefore, it recommended that there should be effective use of money supply and government expenditure as key instruments of monetary and fiscal policy in Nigeria in order to improve the economy. Also, government annual budget implementation and execution of projects should be monitored to ensure that the objectives of the budget is achieved, which include price stability, economic growth, increase employment, income distribution among others. This can be done by eliminating corruption, leakages of resources and inappropriate use of resources. Interest rate should the reduced to one-digit to encourage borrowing, increase investment and output. These will bring the economy to a steady state.
\end{abstract}

Keywords: Monetary Policy, Fiscal Policy, Economic Growth, Error Correction Model

\section{Introduction}

The macroeconomic policy plays crucial role in providing sustainable and credible economic stability in a country, thus creating the environment for the fast economic growth. This task is primarily achieved through monetary and fiscal policies as its fundamental components. But, the necessary precondition for the successful functioning of an economy is the existence of coordinated activities of monetary and fiscal policies, since the absence of this coordination leads to a poor overall economic performance. Although these policies are conducted by two separate authorities, they are mutually dependent, and therefore, it is extremely important to accomplish a consistent and sustainable policy-mix framework, within which monetary and fiscal policies will be harmonized, to avoid possible inconsistencies [22]. While fiscal policy is mainly concerned with the public expenditures and revenues, monetary policy deals with the discretionary control of money supply. Namely, through fiscal policy instruments and measures, modern governments participate in almost every part of social and economic life by influencing aggregate demand and supply, attempting to create the full employment conditions and moderate inflation, leading the policy of stable foreign trade balance and supporting steady economic development. Additionally, prudent and sustainable fiscal posture promotes "noninflationary economic growth, low and stable levels of fiscal deficit and public debt, reduction of budget imbalances in situations of high fiscal deficit and public debt" [12].

On the other hand, monetary policy is mostly focused on accomplishing stability of prices thus avoiding high inflation rates, stable and stimulating exchange rate resulting in positive balance of payment and satisfactory level of 
employment. Besides, it influences the output level and economic growth rate and moderates excessive aggregate liquidity in the economy [28]. Since the late 1970s, fiscal policy has become a major instrument in Nigeria. The reasons for these are not inconsiderable. First is the domestic role of the public sector in major (formal) economic activities in Nigeria. This can be traced to several factors. Among them are oil boom in early 1970s, the need for reconstruction after the civil war, the industrialization strategy adopted at the time (import substitution industrialization policy) and the militarization of governance. The second reason for the increasing dominance of fiscal policy in the management of the economy is the fall in the international price of oil in the late 1980s. Furthermore, the persistent fiscal deficit since the early 1970 s and role of underwriting CBN treasury securities to commercial agents as also influenced the dominance of fiscal actions. Government subsequently opted for discount houses which specialized agency focusing mainly on this function.

Today, money supply and government expenditure are both commonly accorded prominent roles in the pursuit of macroeconomic stabilization in developing countries but the relative importance of both has been a serious debate between the Keynesians and the monetarists. The monetarists believe that money supply exerts greater impact on economic activities while the Keynesians believe that government expenditure rather than the money supply exert greater influence on economic activities. Giving the fact that both money supply and government expenditure have great impact on economic growth, it is not surprising that they are entwined [3]. Fiscal and monetary policies are inextricably linked in macroeconomic management, development in one sector directly affect developments in other. Undoubtedly, fiscal policy is central to the health of any economy, as government's power to tax and to spend affects the disposable income of citizens and corporations, as well as the general business climate. In this regard, the interrelationship between public spending and private sector performance is of paramount importance. On one hand, government expenditure can provide an impulse for private sector growth, while on the other hand, it can be harmful if it results in budgets deficits and leads to competition for scarce financial resources from the banking sector as the government seeks to finance the deficits. In such circumstances, the crowding out of the private sector by the government sector outweighs any short term benefits of an expansionary fiscal policy. The key to all these, therefore, lie in striking a good balance in the fiscal management. Having enough expenditure outlays to meet the needs of government and support growth but not so much as to deny the private sector the resources it need to invest and develop [20].

The problem is that poor management of money supply and government expenditure will lead to increase in general price level, high unemployment rate, balance of payment deficit, unequal distribution of income, poverty etc.

The research questions emanating from the study are:

1) Do monetary policy instruments improve economy activities in Nigeria?

2) Do fiscal policy instruments positive impact on the level of output in Nigeria?

3) Which of the monetary or fiscal policies instruments in more effective in stabilizing Nigerian economy?

This study is structured into five sections. Section one is the introduction discussed above. Section two is Empirical review while section three is the methodology. Section four and five are empirical analysis, conclusion and policy recommendations respectively.

\section{Empirical Review}

Several studies have examined the effectiveness that fiscal policy and monetary policy. The argument about fiscal policy can be dated back to Keynesian times, which predicts that expansionary fiscal policy (increasing government expenditure or decreasing tax) will increase disposable income, and raise the private consumption. However, investment will be partially crowded out because the increase of interest rate. Most of empirical studies support this idea. $[8,24,15]$ confirm the positive effect of government expenditure and revenue on consumption and output.

The study which was carried out in United State using quarterly data and tested three null hypotheses on the effect of fiscal policy relative to monetary policy on economic growth (proxy by government expenditure, money supply and gross domestic product is greater, more predictive and faster). The result of the test is consistent with the alternative hypothesis, the effect of money supplies relative to government expenditure more predictable and faster on growth. The study recommends monetary policy for the purpose of economic stabilization [4]. A cross-selected time series study based on data from seven developed countries outside USA found that money supply exerts more influence on GDP than changes in government expenditure [21]. The result supported the study by Anderson and Jordan study. A study carried out in three Scandinavia countries namely, Denmark, Finland and Norway to determine the relative effectiveness of money supply and government expenditure, it was observed that government expenditure dominates economic activities in all the three countries studied even after transforming the results to beta and elasticity coefficients [29]. The results therefore contradicted the earlier conclusions by Anderson and Jordan collaborated by that of Keran. The original data of (1933-1968) was extended by [16] used in the study of [4] to 1976, his empirical research found that government expenditure becomes significant. Though, [10] was of the opinion that Friedman was suffering from the problem of heteroscedastcity and suggested that the regression should be estimated in percentage first difference form.

A research in 15 African countries including Nigeria done by [30] which used three variables: GDP, money supply $\left(\mathrm{M}_{1}\right)$ and total government expenditure $(\mathrm{G})$. Time series data spanning 17 years were obtained from them; first and second differences were calculated and applied to obtained 
regression estimates like in the early studies, beta coefficients of the monetary and fiscal instruments were computed for direct comparison of the impact coefficients. The result indicated non-existence of serial correlation in the data. Moreover, chow test confirms the structural stability of the model. On the basics of findings, Ubogu recommends the need for policy tool for purpose of selecting the correct stabilization instruments.

A study titled the role of fiscal and monetary policies in a depressed economy, a case study of Nigeria extricated a slightly modified form of St. Louis equation. Data from 1986-1991 was employed, the analysis of their results showed that fiscal policy exerts more influence on the economy than monetary policy. The result, therefore, suggests that fiscal policy have been more effective in Nigeria at least in the point of depression. They are however, of the opinion that government expenditure will be an appropriate measure of fiscal policy [27]. A modified version of the St. Louis equation was adopted by [6] as in [7] and provide estimates based on first differences and percentages changes of the data. The results also include the respective tratios, beta elasticity coefficient to facilitate direct comparisons. The result of the estimate showed that coefficients of money supply were statistically significant while those of government expenditure were not significant. This agrees with the hypothesis that monetary actions are more potent than fiscal policy. However, coefficient of export is not significant and this confirms earlier results by [30] such that exclusion of export variable in the earlier studies in Nigeria and that emphasis on fiscal action of the government has led to greater distortion in the economy. However, the study recommends that both policies should be complementary.

A study on the relative effectiveness of monetary and fiscal policy on economic activity in Nigeria was determined through co-integration and error correction modeling techniques. The time series properties of the variables were investigated by conducting a unit root test using annual series data for the period 1970-1998. The result of our analysis shows that monetary rather than fiscal policy exerts a great impact on economic activity in Nigeria. The emphasis on fiscal action of the government has led to greater distortion in the Nigerian economy. We are, however, of the opinion that both monetary and fiscal policies should be complementary [3].

An empirically work examined the relative effectiveness of fiscal and monetary policy on economic growth in Nigeria. Annual time series data from 1970 - 2007 is employed. Error correction mechanism and co-integration technique have been used in the study. Gross domestic product, broad money, government expenditure and degree of openness have been used in the study. Results indicate that the effect of monetary policy on economic growth in Nigeria is much stronger than fiscal policy. They recommended that policy makers should emphasize on monetary policy for the purpose of economic stabilization in Nigeria [1]. An investigation on the comparative effect of fiscal and monetary policy on economic growth in Pakistan using annual time series data from 1981 to 2009 using co-integration test, confirms positive long run relationship between monetary and fiscal policy with economic growth. However, monetary policy is found to be more effective than fiscal policy in enhancing the economic growth of Pakistan. They suggested that policy makers should focus more on monetary policy than fiscal policy to ensure economic growth however; the short run relationship should also have been checked [19].

An Econometric investigation on the relative effectiveness of monetary and fiscal policies conducted by [18] focused on the relative effectiveness of broad money supply and government fiscal deficits with respect to their influences on economic activity represented by the gross domestic product (GDP). Two equations were estimated on the relative effectiveness of monetary vis-à-vis fiscal policy. The model was an adaptation and subsequent modification of the St. Louis model of the Federal Reserve Bank of USA by [4]. They used error correction mechanism with annual time series data for the period 1970 through 2001. The results of the study confirmed [9] result that the contemporaneous contribution of broad money supply $\left(\mathrm{MS}_{2}\right)$ to the inflationary cycle in Nigeria is weak, but it one year lagged value is strong, positive and significant. The effects of Money Supply factors on inflation in Nigeria appear dominant, while the role of fiscal deficit is pervasive. The study also confirmed that the role of fiscal policy (especially fiscal deficits) although positive, is negligible and in some instances statistically insignificant in influencing cyclical inflation rate in Nigeria within the period under review. Output model confirms that money matters in Nigeria and that the appropriate monetary target is the Broad Money Supply. It concludes that the effect of monetary policy on output growth has an edge over fiscal policy variable as a measure of output stabilization while fiscal policy efforts of the Federal Government of Nigeria are not positive in stimulating output growth.

The study of [5], however, suggested that monetary influence is relatively stronger and more predictable than fiscal policy in determining economic activity in Zimbabwe. Nevertheless, [24] found no significant role for monetary policy but have support for fiscal policy. Contrary to this finding, [13] revealed that monetary policy in a developing country plays an important role in increasing the growth rate of the economy by controlling inflation and maintaining equilibrium in the balance of payments.

A research conducted by [11] examined the impact of monetary and fiscal Policies on Nigerian economic growth: 1990-2010. VAR model and graph were some of the econometrics techniques used for data estimation. Phillipperron test statistic revealed that the time series properties of the variables attained stationarity at first order. The variables were co integrated at most 1 with at least 2 co-integrating equations. The variable used are: minimum rediscount rate, interest rate, liquidity rate, cooperate income tax, federal budget and gross domestic product. From their results, federal budget is not statistically significant to gross domestic 
product. However, interest rate and liquidity rate impacted negatively on the GDP but minimum rediscount rate cooperate income tax and federal budget affect the GDP positively. The reaction of monetary and fiscal policies measure on the level of economic growth in Nigeria was found to be unstable over the years of study which indicated no long run relationship. However, the study further revealed that fiscal policy measures are more effective in gearing economic growth in Nigeria. The study recommended that there should be effective strategic policies that enhance better fiscal policy implementation in Nigeria that will in the long run contribute to the national economic growth and also more robust and viable monetary policy measures should be made to achieve sound economic growth.

The research of [20] on the analysis of Nigeria democracy and its impact on fiscal and monetary policies adopted descriptive statistics, regression and correlation analysis on fiscal and monetary variables (i.e., inflation, interest rate, narrow money, broad money, government recurrent and capital expenditure). The results revealed that there has been fluctuation in the trend of policy variables in Nigeria (i.e., inflation rate, interest rate, narrow money, broad money, government re-current and capital expenditure) considered with reference to the stable democracy in Nigeria (19992008). The results also show that $96.3 \%$ of the variation (model 1) has been explained by the explanatory variables, $98.1 \%$ of the variation in dependent variable (model 2) has been explained by the explanatory variable, $99.4 \%$ of the total variation in dependent variable has been explained by the explanatory variables (model 3 ) and $85.7 \%$ of the variation in dependent variable (model 4 ) has been explained by the explanatory variables. The results further showed that broad money and re-current expenditure have positive relationship with RGDP. The correlation results further showed that narrow money, broad money and government recurrent expenditure are significant at $1 \%$ probability level while government capital expenditure is significant at $5 \%$ probability level with inflation and interest rate having no significant relationship and negatively related with RGDP. The study concluded that narrow money, broad money, government recurrent expenditure and capital expenditure are significant variables that affect economic growth in Nigeria.

The empirical link on the effect of fiscal and monetary policy on the Economic Growth of Nigeria (1986-2010) conducted by [26]. The study employed the ordinary least squares method of statistical analysis. Two models were used. Model I is the fiscal model while model II is the monetary model. It was found out that government revenue had a positive impact and statistical significant on gross domestic product. Government expenditure was also positively significant on the growth of Nigeria Economy. The second model depicts that money supply had a positive impact on gross domestic product and it discovered that this variable was statistically significant. Exchange rate variable had a positive impact on the performance of Nigeria economy. The finding revealed that inflation had a positive impact but there was no significant relationship between inflation and gross domestic product. It therefore suggests that government should increase the number of fiscal policy instruments over and above the ones currently in use. The study recommended that measures should be adopted that would ensure income generation and government revenue generating ventures.

An empirical study by [17] on the relative importance of monetary and fiscal policy on economic growth in Ghana and to determine which of these two policies is more powerful in promoting economic growth in Ghana. The study used time series data from 1980 to 2012 and Ordinary Least Squares estimation technique. They used three multiple regressions and showed that monetary policy impacts is potent in Ghanaian economy. Also, the study found that fiscal policy is also effective in Ghanaian economy. Comparing the impact of both policies on Ghana's economy, the study revealed that monetary policy is more effective in promoting economic growth in Ghana than fiscal policy. The study recommends that monetary policies implemented by the Bank of Ghana should promote favourable investment atmosphere through appropriate stabilization of interest rates, lending rates, inflationary rates, and exchange rates to promote and ensure economic growth, economic stability, economic sustainability and economic development in Ghana.

In his study, [14] examined the relative effectiveness of fiscal and monetary policy instruments on economic growth sustainability in Nigeria. The methodology employed is error correction mechanism whereby the time series properties of fiscal and monetary variables were first examined using Augmented Dickey-Fuller and Philip Perron unit root tests, followed by Johansen co-integration test among the series using annual data for the period 1970-2013. The result suggests that there is a long run relationship among fiscal and monetary variables and economic growth. It however, found that the current level of exchange rate and its immediate past level, domestic interest rate, current level of government revenue and current level of money supply are the appropriate policy instrument mix in promoting economic growth both in the short and long run. The paper concluded that fiscal and monetary are still complementary.

The work carried out by [2] on the relative impact of money supply and government expenditure on economic growth in Nigeria. The beta Coefficients techniques and Two Stage Least Square were employed to analyse the data. Using three different models, monetary model, fiscal model and monetary and fiscal model; the empirical result showed that broad money supply is more effective among the two monetary policy instruments (broad money supply and interest rate). While the fiscal model, government expenditure is more potent than any of the other two fiscal policy instruments (tax revenue and budget deficit). On the third model (monetary and fiscal), the result showed that government expenditure is relatively more effective compared with money supply on economic activities. They found out that the impact government expenditure as a fiscal policy instrument is greater, more reliable (predictable) and faster in stabilizing the Nigerian economy than money supply 
as a monetary policy instrument. They therefore advised that both policy instruments can be mixed to bring about economic growth and stability for Nigeria.

\section{Methodology}

\subsection{Theoretical Framework}

From the empirical reviews, it had been noted that there is some consensus that money supply and government expenditure are two key instruments of monetary and fiscal policy. However, there is a considerable amount of agreement about the relative impact of these actions. It was also noted that basic macro-static and dynamic analysis of the relative effectiveness of these instruments, based on the Hicksian ISLM framework reveal that change in the government expenditure, representing fiscal policy, is completely effective in Keynesian or liquidity trap region, where the demand for money is perfectly interest elastic, some that effective is the neo-Keynesian region (i.e. positive slope LM curve) where the demand for money exhibit an interest elasticity (which is positive and finite) and completely ineffective in the classical region in which LM curve is vertical and the demand for money is perfectly interest inelastic. The effectiveness of money supply is the reverse of that of government expenditure in the liquidity trap that is; money supply is completely ineffective in the liquidity trap but fully effective in the classical or vertical LM region, and how effective in the intermediate neo-Keynesian region. This region, which is that situation of most economics, calls for monetary-fiscal mix [6].

\subsection{Model Specification}

On the basis of empirical studies, the study will use Error Correction Model (ECM) adapted from the work of [3] on the relative effectiveness of fiscal and monetary policy in macroeconomic management in Nigeria. The structural model is stated thus:

$$
\mathrm{GDP}=\mathrm{f}(\mathrm{MS}, \mathrm{INT}, \mathrm{EXP}, \mathrm{REV}, \mathrm{DEF})
$$

Where Gross Domestic Product (GDP), endogenous variable and, broad Money Supply (MS), Interest Rate (INT), Government Expenditure (GEX), Revenue (REV) and Budget Deficit (BDF) as exogenous variables. The study investigates the relative effectiveness of monetary and fiscal policy instruments in stabilizing Nigerian economy covering the period between 1970 to 2015 . The linear and multiple regression is expressed thus:

$$
\mathrm{GDP}_{\mathrm{t}}=\beta_{0}+\beta_{1} \mathrm{MS}+\beta_{2} \mathrm{INT}+\beta_{3} \mathrm{EXP}+\beta_{4} \mathrm{REV}+\beta_{5} \mathrm{DEF}+\mu_{\mathrm{t}}
$$

The apriori expected posed that all the independent variables would produce a positive relationship with the dependent variable except interest rate. Therefore, $\beta_{1}, \beta_{3}, \beta_{4} \&$ $\beta_{5}>0$ while $\beta_{2}<0$.

In order to avoid spurious results, as observed in many past studies, unit root tests were first carried out on each series in equations (2) using both the Augmented DickeyFuller (ADF) test. Co-integration tests were also examined through Johansen co-integration techniques and these were followed by the estimation of equations (2) using Error Correction Modelling (ECM) techniques.

\section{Empirical Analysis}

The result presented in this section are based on all test stated in chapter three. All results to be analysed in this chapter are computed using Microfit 5.0 and Eviews 9.0 statistical software packages. The Augmented Dickey-Fuller test will be used to test for unit root. All the variables were regressed on trend and intercept to determine if they have trend, it was discovered that the six variables have trend and intercept, hence the unit root test involve trend and intercept. The result is presented:

\subsection{Stationarity Result}

Table 1. Unit Root Stationarity Result.

\begin{tabular}{llll}
\hline Variable & $\begin{array}{l}\text { ADF } \\
\text { Statistics }\end{array}$ & Critical Value & $\begin{array}{l}\text { Stationary } \\
\text { Status }\end{array}$ \\
\hline \multirow{2}{*}{ GDP } & -7.460302 & $-4.26274(1 \%)$ & \\
& & $-3.55297(5 \%)$ & $\mathrm{I}(1)$ \\
& $-3.20964(10 \%)$ & \\
MS & $-4.26274(1 \%)$ & \\
& -8.382534 & $-3.55297(5 \%)$ & $\mathrm{I}(1)$ \\
& & $-3.20964(10 \%)$ & \\
INT & & $-4.26274(1 \%)$ & \\
& -6.009893 & $-3.55297(5 \%)$ & $\mathrm{I}(1)$ \\
& & $-3.20964(10 \%)$ & \\
GEX & & $-4.26274(1 \%)$ & $\mathrm{I}(0)$ \\
& -4.611492 & $-3.55297(5 \%)$ & \\
REV & & $-3.20964(10 \%)$ & \\
& & $-4.5743(1 \%)$ & \\
& & $-3.6920(5 \%)$ & $\mathrm{I}(1)$ \\
BDF & -5.860210 & $-3.2856(10 \%)$ & \\
& & $-3.5743(1 \%)$ & \\
\hline
\end{tabular}

Source: Author's Computation

The critical values for rejection of hypothesis of unit root were from [23] as reported in e-views 9.0.

The six variables (GDP, MS, INT, GEX, REV and BDF) underwent unit root test using the Augmented Dickey-Fuller (ADF) test. As is the case most times, all three variables were found to be non-stationary at levels except GEX which was stationary at levels. The remaining five variables (GDP, MS, INT, REV and BDF) were found to be stationary after first difference.

\subsection{Co-Integration}

Table 2. Johansen Cointegration Test.

\begin{tabular}{lllll}
\hline \multicolumn{6}{l}{ Unrestricted Cointegration Rank Test (Trace) } \\
\hline Hypothesized & & Trace & $\mathbf{0 . 0 5}$ & \\
\hline No. of CE(s) & Eigenvalue & Statistic & Critical Value & Prob.** \\
None $*$ & 0.963619 & 305.0857 & 159.5297 & 0.0000 \\
At most $1 *$ & 0.938099 & 212.3017 & 125.6154 & 0.0000 \\
At most $2 *$ & 0.789378 & 134.3995 & 95.75366 & 0.0000 \\
\hline
\end{tabular}




\begin{tabular}{lllll}
\hline \multicolumn{6}{l}{ Unrestricted Cointegration Rank Test (Trace) } \\
\hline Hypothesized & \multicolumn{5}{l}{ Trace } & $\mathbf{0 . 0 5}$ & \\
\hline At most $3 *$ & 0.667567 & 90.78417 & 69.81889 & 0.0005 \\
At most 4 & 0.582308 & 59.94733 & 47.85613 & 0.0025 \\
At most 5* & 0.488658 & 35.50303 & 29.79707 & 0.0099 \\
\hline
\end{tabular}

Trace test indicates 7 cointegrating equations(s) at the 0.05 level

* denotes rejection of the hypothesis at the 0.05 level

**MacKinnon-Haug-Michelis (1999) p-values

Source: Author's own computation using E-Views Software, Version 9.0
The table 2 above shows the long run relationship existing among the variables of study. The table shows the variables converge in the long run thereby depicting the existence of long run relationship among them. The long run relationship exists at $5 \%$ level of significance according to the Trace test statistics and the Eigenvalue. This implies there exists five (5) co-integrating relationship among the variables. Therefore there is long run relationship among the variables.

Table 3. Error Correction Mechanism.

Dependent Variable: $\triangle G D P$

\begin{tabular}{llll}
\hline Independent Variables & Coefficient & Standard Error & t-Statistic \\
\hline Constant Intercept & -62462.42 & 17761.16 & -3.516798 \\
$\Delta \mathrm{MS}_{\mathrm{t}}$ & 11824.59 & 945.7305 & 12.50313 \\
$\Delta G E X_{\mathrm{t}}$ & 0.002521 & 0.001290 & 0.0126 \\
$\Delta \mathrm{INT}_{\mathrm{t}}$ & -1022.967 & 837.2071 & 0.0000 \\
$\Delta \mathrm{REV}_{\mathrm{t}}$ & 1.024911 & 0.012171 & 0.0319 \\
$\Delta \mathrm{BDF}$ & 12.41934 & 5.923431 & 0.0651 \\
$\mathrm{ECM}\left(\mu_{\mathrm{t}-1}\right)$ & -0.111929 & 0.035809 & 3.104332 \\
$\mathrm{R}^{2}$ & 0.566073 & F Statistic & 2.432753 \\
Adjusted $\mathrm{R}^{2}$ & 0.512817 & $\mathrm{D}-\mathrm{W}$ Statistic & -3.125736 \\
\hline
\end{tabular}

Source: Author's Computation

Since the variables were found to be co-integrated implying that they have long run equilibrium relationship, it is necessary to test for short run relationship. From table 3, the ECM parameter is negative (-) and significant which is 0.111929 , this shows that 11 per cent disequilibrium in the previous period is being corrected to restore equilibrium in the current period. It has been established the variables are co-integrated and also have short run relationship established from the ECM. Hence, the OLS technique will be used to derive the long-run impact of the independent variables (MS, INT, GEX, REV and BDF) on the dependent variables (GDP).

\subsection{Regression Result}

Table 4. General Regression Result.

Dependent Variable: GDP

\begin{tabular}{llll}
\hline Independent Variables & Coefficient & Standard Error & t-Statistic \\
\hline Constant Intercept & -62462.42 & 17761.16 & -3.516798 \\
MS & 0.005521 & 0.001290 & 4.954225 \\
GEX & 11.82459 & 0.9457305 & 12.50313 \\
INT & -102.2967 & 83.72071 & -1.221881 \\
REV & 0.004335 & 0.001939 & 4.00192 \\
BDF & -8.499385 & 1.983839 & 0.00017 \\
R & 0.866097 & F-Statistic & 0.00000 \\
Adjusted R & & D-W Statistic & 0.00019 \\
\hline
\end{tabular}

Source: Author's Computation

\subsection{Interpretation of Results}

From the result in table 4, it is therefore, inferred that a unit increase in money supply (MS) on the average holding other independent variables constant will lead to 0.005521 unit increase in economic growth. This shows that money supply has a positive impact on economic growth with the impact being statistically significant going by the low probability value. This result fulfils apriori expectation and is consistent with other results on monetary policy and economic growth in Nigeria. In the same vein, suggest that a unit increase in government expenditure (GEX) on the average holding other independent variables constant will lead to 11.82459 unit increases in economic growth. This shows that government expenditure has a positive impact on economic growth with the impact being statistically significant going by the low probability value. This result fulfils apriori expectation and is consistent with other results on monetary policy and economic growth in Nigeria. Also, a unit increase in interest rate on the average holding other independent variables constant will lead to 102.2967 unit decrease in economic growth. This shows that interest rate (INT) has a negative impact on economic growth with the impact being statistically insignificant going by the high probability value. This result conforms to apriori expectation. A unit increase in revenue (REV) on the average holding other independent variables constant will lead to 0.004335 unit increase in economic growth. This shows that revenue has a positive impact on economic growth with the impact 
being statistically significant going by the low probability value. This result conforms to apriori expectation.

Finally, a unit increase in budget deficit (BDF) on the average holding other independent variables constant will lead to 8.499385 unit decreases in economic growth. This shows that budget deficit has a negative impact on economic growth with the impact being statistically significant going by the low probability value. This result negates the apriori expectation of BDF. The R-Squared shows that the model is a good fit with 0.866097 (86\%) change in economic growth accounted for by change in the independent variables. This implies that 86 percent of the change in economic growth was explained by changes in the independent variables. The Adjusted $\mathrm{R}^{2}$ is given as 0.862817 (86 percent). This means that precisely 86 percent of the variations in the growth rate Gross Domestic Product of Nigeria are accounted for by the included variables, after the co-efficient of determination $\left(\mathrm{R}^{2}\right)$ has been adjusted to make it insensitive to the number of included variables. In addition, the F-statistic supports this position with its result showing that the model is significant and well specified. From the critical F value 24.4697 was obtained. This probability value is less than 0.05 (5\% level of significance), leading us to reject the null hypothesis of insignificant model implying that the independent variables are significant explanatory factors of the economic growth in the long run.

Cumulative Sum Test for Model Stability

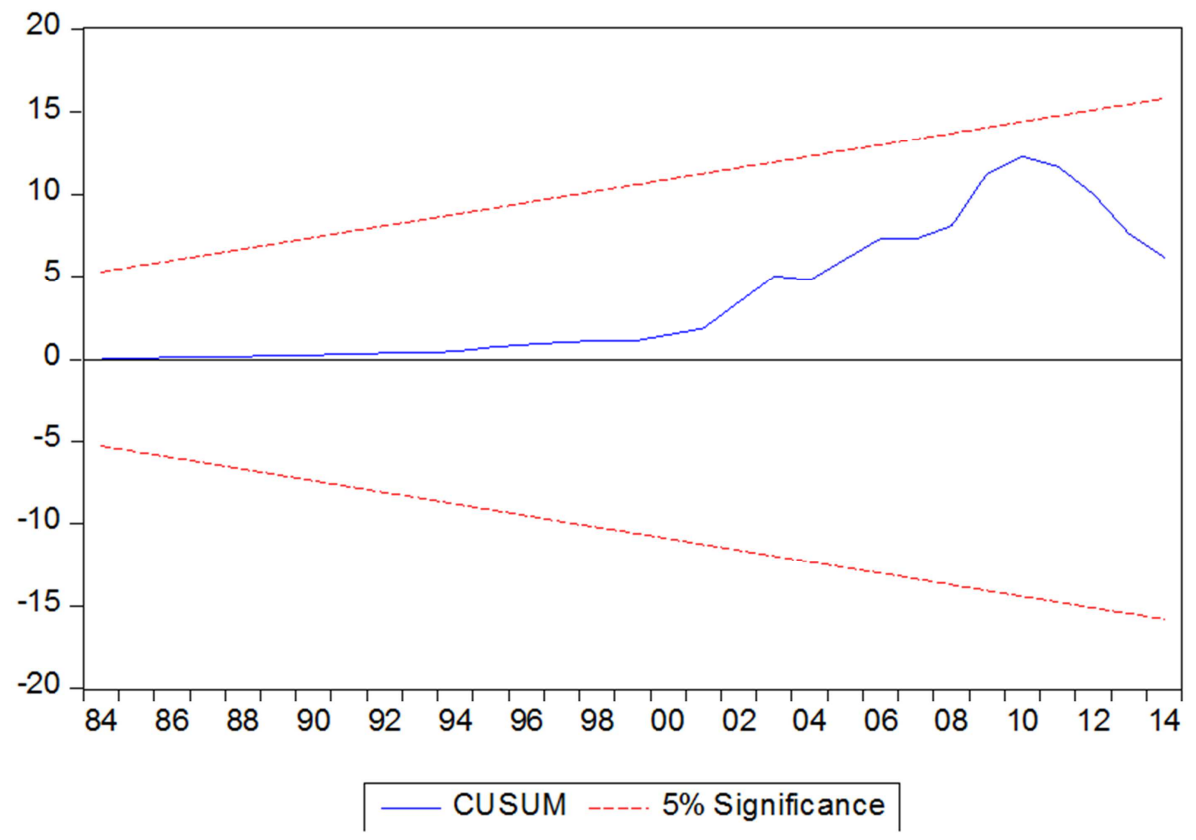

Figure 1. CUSUM TEST.

Figure 1 above shows the cumulative sum which is used to test for model stability in least square estimates. The CUSUM falls within the critical region of five percent level of significant over the period investigated. This shows that the parameters are stable over the sample period studied $(1980-2015)$. The test indicates that the parameter estimates are reliable and can be used for inference.

\section{Conclusion and Policy Recommendations}

The evidences from analyses from this study revealed that, there exist a short-run and long-run relationship between monetary and fiscal policy instruments and economic growth in Nigeria. This was confirmed by the positive relationship between money supply, government expenditure and revenue while interest rate and deficit finance have negative relationship with economic growth. The negative relationship between interest rate and economic growth can be attributed to the continuous increase in interest rate which indeed has discouraged borrowing, reduce investment, reduce output and increase unemployment rate. The persistence increase in deficit finance by the federal government of Nigeria has little or no impact in the lives of the citizens. This confirms the corrupt nature of those in government where funds allocated for capital projects are diverted to private pockets and the funds also get into the economy without an increase in output, hence an increase in the general prices level. It can be noted that money supply and government expenditure as key instruments of monetary and fiscal policy impact positively on economic growth. It is recommended among others that the effective use of money supply and government expenditure as key instruments of monetary and fiscal policy in Nigeria to improve economy. The government annual budget implementation and execution of projects should be monitored to ensure that the objectives of the budget is achieved, which include price stability, economic growth, increase employment, income distribution among others. This can be done by eliminating corruption, leakages of resources and inappropriate use of resources. Interest rate 
should the reduced to one-digit to encourage borrowing, increase investment and output.

\section{References}

[1] Adefeso, H. A. \& Mobolaji, H. I. (2010). The Fiscal-Monetary Policy and Economic Growth in Nigeria: Further Empirical Evidence. Pakistan Journal of Social Sciences, 7(2), 137-142.

[2] Adegoriola, A. E. \& Siyan, P. (2015). The Relative Impact of Money Supply and Government Expenditure on Economic Growth in Nigeria. Economy, [S. 1.], 2(3), 49-57.

[3] Ajisafe, R. A. \& Folorunso, B. A. (2002). The Relative Effectiveness of Fiscal and Monetary Policy in Macroeconomic Management in Nigeria. The African Economic and Business Review, 3(1), 23-40.

[4] Anderson, L. C. \& Jordan, J. L. (1968). Monetary and Fiscal Action: A Test of their Relative Importance in Economic Stabilization, Monthly Review, Federal Reserve Bank of St. Louis (November).

[5] Anna, G. (2012). The Relative Effectiveness of Monetary and Fiscal Policies on Economic Activity in Zimbabwe 1981:4 1998:3): An Error Correction Approach. International Journal of Management Sciences and Business Research, 1(5): 1-35.

[6] Asogu, J. O. (1998). An Econometric Analysis of the Relative Potency of Monetary and Fiscal Policy in Nigeria, CBN Economic and Financial Review, 36(2), 30-63.

[7] Batten, D. S. \& Hafer, R. W. (1983). The Relative Impact of Monetary and Fiscal Actions on Economic Activity: A Cross Country Comparison. Federal Reserve Bank of St. Louis Review (January), 5-12.

[8] Blanchard, O. \& Perotti, R. (1996). An Empirical Characterization of the Dynamic Effects of Changes in Government Spending on Output. NBER Working Paper 7296.

[9] Bogunjoko, J. O. (1997). Monetary Dimension of the Nigerian Economic Crisis: Emprical Evidences from a Conintegration Paradigm. Nigerian Journal of Economic and Social Studies, 39(2), 145-167.

[10] Carlson, K. M. (1978). Does the St Louis Equation now Believe in Fiscal Policy? Federal Reserve Bank St Louis Review, 13-19.

[11] Chigbu, E. E. \& Njoku, M. (2013). The Impact of Monetary and Fiscal Policies on Nigerian Economic Growth: 19902010. European Journal of Business and Management, 5(2).

[12] Chukuigwe, E. C. \& Abili, I. D. (2008). An Econometric Analysis of the Impact of Monetary and Fiscal Policies on Non-Oil Exports in Nigeria: 1974-2003. African Economic and Business Review, 6(2), 59-73.

[13] Ezigbo, C. (2012). Justification and Implication of Macroeconomic Management for Sustainable Development. Journal of Economics and Sustainable Development, 3(11): 72-82.

[14] Falade, O. E. \& Folorunso, B. A. (2015). Fiscal and Monetary Policy Instruments and Economic Growth Sustainability in Nigeria. American Journal of Economics, 5(6): 587-594 DOI: 10.5923/j.economics.20150506.04

[15] Fatas, A. \& Mihov, I. (2003). The Case for Restricting Fiscal Policy Discretion. Oxford Review of Economic Policy, 19(1), 112-131.

[16] Friedman, B. M. (1977). Even the St. Louis now Believes in Fiscal Policy. J. Money Credit Bank, 9: 365-369.

[17] Havi, E. D. K. \& Enu, P. (2014). The Effect of Fiscal Policy and Monetary Policy on Ghana's Economic Growth: Which Policy is More Potent? International Journal of Empirical Finance, (3)2, 61-75.

[18] Iyeli, I. I., Uda, E. B. \& Akpan E. (2012). The Relative Effectiveness of Monetary and Fiscal Policies in Economic Stabilization in a Developing Economy: An Empirical Evidence from Nigeria. African Journal Online, 3(1).

[19] Jawaid, S. T., Arif, I. \& Naeemullah, S. M. (2010). Comparative Analysis of Monetary and Fiscal Policy: A Case Study of Pakistan. NICE Research Journal, 3, 58-67.

[20] Kareem, R. O., Afolabi, A. J., Raheemand, K. A. \& Bashir, N. O. (2013). Analysis of Fiscal and Monetary Policies on Economic Growth: Evidence from Nigerian Democracy. Current Research Journal of Economic Theory, 5(1): 11-19.

[21] Keran, M. W. (1970). Monetary and Fiscal Influence on Economic Activity, Federal Reserve Bank of St. Louis Review, (52), 5-24.

[22] Kvrgić, G., Čolić, Z., \& Vujović, T. (2011). Značaj koordinacije meramonetarne ifiskalne politik. Bankarstvo, 40(3-4), 32-61.

[23] MacKinnon J. G. (1990). Critical Values for Cointegration Tests, Queen Economics Department Working Paper No. 1227.

[24] Mountford and Uhlig (2008). What are the Effects of Fiscal Policy Schocks? The National Bureau of Economic Research. Working Paper No. 14551.

[25] Munongo, S. (2012). Effectiveness of Fiscal Policy in Economic Growth: The Case of Zimbabwe. International Journal of Economics Research, 3(6), 93-99.

[26] Ogar, A., Nkamare, S. E. \& Emori, E. G. (2014). Fiscal and Monetary Policy and its Effect on the Growth of Nigeria Economy. European Journal of Business and Management. $6(29)$.

[27] Olaloye, A. O. \& Ikhide S. I. (1995). Economic Sustainability and the Role of Fiscal and Monetary Policies in A Depressed Economy: The Case Study of Nigeria", Sustainable Development 3, 89-100.

[28] Rakić, B. \& Rađenović, T. (2013). The Effectiveness of Monetary and Fiscal Policy in Serbia. Industrija, 41(2). DOI: 10.5937/industrija41-4011.

[29] Teigen, R. L. (1973). Monetary and fiscal influences on economic activity: Evidence from Denmark, Finland, and Norway. Issue 32 of Institute for International Economic Studies, University of Stockholm.

[30] Ubogu, R. E. (1985). Potency of Monetary and Fiscal Policy Instruments on Economic Activities of African Countries; Finafrica: Savings and Development, 9(4), 440-457. 